\title{
Dwa apokryfy Różewicza w kontekście kilku wersów Księgi Jeremiasza
}

\author{
Słowa najpokorniejsze, najlichsze \\ Bo nimi napisana została Ewangelia ${ }^{1}$.
}

Poezja Różewicza ma głęboko apokryficzny charakter, momentami ociera się o mistycyzm, a w swoim całościowym wymiarze jest wielką opowieścią o zmaganiu się z Bogiem i modlitwą o wiarę. Dano już wiele wytłumaczeń tego stanu rzeczy i nie można zasadnie powiedzieć, że straciły one na swojej aktualności. Jednak z biegiem czasu można odkryć kolejne pokłady znaczeń, które zasłaniane były przez dobierane dotąd metody i dominujące paradygmaty filozoficzne. Czytano Różewicza jako nihilistę, moralistę, ateistę itd. Jak sądzę, wymyka się on jednak tym kategoryzacjom. Dlatego właśnie interpretowanie całości poetyckiego dzieła autora Niepokoju przez pryzmat intertekstu biblijnego wydaje się konieczne, aby choć podjać próbę dopełnienia obrazu najistotniejszych kwestii, które ta poezja porusza. Celem niniejszego artykułu jest reinterpretacja dwóch tekstów autora Niepokoju w duchu hermeneutyki, by — po pierwsze — pokazać choć fragment Różewiczowskich apokryfów i — po drugie — inaczej odczytać wybrane przez siebie teksty. Pierwszym z nich jest Nieznany list, drugim — *** rzeczywistość ${ }^{2}$.

\section{I}

Nieznany list to tekst trudny. Nagromadziło się wokół niego wiele interpretacji, które często są z sobą sprzeczne. Tytuł w zestawieniu z wiadomością, iż tekst traktuje o epizodzie z życia Jezusa, wskazuje na apokryficzny wymiar tekstu. List miałby być adresowany do matki Chrystusa.

\footnotetext{
${ }^{1}$ L. Staff, Arkana, [w:] idem, Wiersze zebrane, t. V, Warszawa 1955, s. 195.

2 Wiersze cytuję za: T. Różewicz, Utwory zebrane, [tu: Poezja], Wrocław 2002-2004.
} 


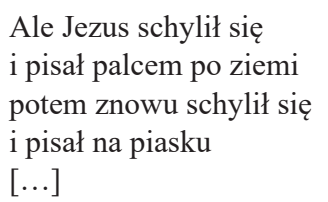

Pierwsze wersy, jeżeli czytać je bez ewangelicznego i starotestamentalnego kontekstu (ten drugi — niewydobyty dotychczas przez badaczy — wydaje mi się istotniejszy) oznaczałyby jedynie nietrwałość słów Chrystusa. Pierwsze wersy nawiązują jednak bezpośrednio do sceny z Ewangelii św. Jana, w której Jezus nie potępia cudzołożnicy przyprowadzonej do niego przez faryzeuszy. Żydzi doskonale znali te fragmenty Księgi Jeremiasza, w których prorok przemawiał, gdy Bóg opuścił niewiernych Izraelitów: „Nadziejo Izraela, Panie! Wszyscy, którzy Cię opuszczają, będą zawstydzeni. Ci, którzy oddalają się od Ciebie, będą zapisani na ziemi, bo opuścili źródło żywej wody, Pana" $(\mathrm{Jr} 17,13)^{3}$. Fragment z Ewangelii św. Jana nawiązuje zatem do prorockiej księgi Jeremiasza. Słowa zapisane na piasku to słowa potępienia - na szczęście dla ludzkości - słowa nietrwałe, ulotne, słowa, które zostaną ,zasłonięte i wymazane/ [...] na wieki”, do czego jeszcze powrócę przy komentarzu do strofy trzeciej.

\section{II}

Matko są tak ciemni

i prości że muszę pokazywać

cuda robię takie śmieszne

$[\ldots]$

Fragment ten doskonale podkreśla zarówno boską, jak i ludzką naturę Jezusa. Jest on zniecierpliwiony faktem, iż musi zniżać się do epifanii w postaci śmiesznych cudów. Zniecierpliwienie podkreślone pejoratywnie nacechowanym kolokwializmem „ciemni” jest wyraźne i to właśnie ono demaskuje tę ludzką naturę Chrystusa. Jezus odczuwa emocje - także te powszechnie uznane za negatywne czy nieprzyjemne. Czyni on jednak cuda. By podkreślić, że są one śmieszne i nieznaczące, poeta korzysta z czasownika „robić”. Jezus nie czyni, on robi cuda. Patetyczny biblijny styl domagałby się tu leksemu „czynić”. Czasownik „robić” rozwarstwia utarte językowe zwroty, przez co wydobywa subtelnie lekceważące zabarwienie tej frazy. Dość interesującym tropem jest uznanie boskości Chrystusa. Leszek Szaruga pisze, że „gdy się zastanowić, wówczas treść owego »nieznanego listu« nie podważa cudowności uczynków Jezusa, co wskazuje na ich zbędność: uczniowie winni słuchać tego, co mówi, gdyż jego słowa i bez cudów zachowują swe znaczenie" który pisze, iż: „Różewiczowski Jezus-cudotwórca to iluzjonista. Jego znaki nie

3 Wszystkie cytaty pochodzą z Biblii Tysiaclecia (wyd. V, Poznań 2014).

${ }^{4}$ L. Szaruga, Ludzki język muz. Czytanie Różewicza, Wrocław 2008, s. 10. 
odsyłają do prawd Bożych, ale pełnią wyłącznie funkcję fatyczną: podtrzymują kontakt z tłumem" ". Nie sposób nie zgodzić się ze stwierdzeniem, iż cuda czynione przez Chrystusa mają znamiona prestidigitatorstwa właśnie ze względu na swą funkcję, którą Kruszewski trafnie wyartykułował. Przyczyną jednak tych cudów nie jest posługiwanie się iluzjonistycznymi efektami, lecz boska natura Chrystusa nakładająca się na naturę ludzką. Natura boska powoduje cuda. Natura ludzka zaś sprawia, że są to cuda nieważne, śmieszne i służą tylko podtrzymaniu kontaktu $\mathrm{z}$,ciemnymi apostołami”.

\section{III}

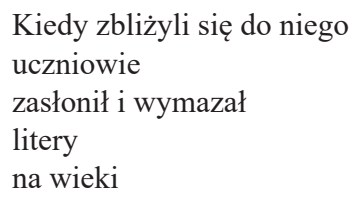

Według Rychlewskiego gest wymazania ma świadczyć o niemożności poznania Tajemnicy. Wynikać to ma z faktu, iż językowy klucz do Transcendencji znajduje się poza zasięgiem poznającego podmiotu ${ }^{6}$. Warto dla przykładu przytoczyć opinię Michała Januszkiewicza, która jest reprezentatywna dla opinii badaczy o tym tekście:

A jednak list pisany przez Jezusa musi pozostać nieznany: pismo się rozmazuje, rozszczepia, rozsuwa. W ten sposób znaleźliśmy się w kręgu myśli Derridy. Jeżeli wiemy, że to, co rozumie on przez pismo (resp. Pra-pismo) to miejsce, w którym wydarza się wszelka komunikacja, przesłania, sens, metafory itp., to przecież wiemy również, że zdaniem francuskiego filozofa pismo jest tym, co się zaciera, przerywa, rozsypuje na piasku, można by wręcz powiedzieć, że samo stanowi praktykę przerywania, a przeto nie pozwala się zatrzymać i uchwycić jak to, co czytelne, jednoznaczne, zrozumiałe. Skoro tak, to czy gest Różewiczowskiego Jezusa nie byłby gestem dekonstrukcyjnym: „czytajcie: nie ma nic do odczytania"7?

Moim zdaniem nie jest to gest destrukcyjny, a wręcz przeciwnie. Przyjmując wykładnię Nieznanego listu skonstruowaną przez Januszkiewicza, wiersza nie można nie czytać jako utworu o utracie dostępu do rzeczywistości prawdziwej, ukryciu klucza do rzeczywistości, wymazaniu kodu do prawdy. Wydźwięk wiersza jest jednak optymistyczny i pełen nadziei, jeśli posłużymy się kontekstem Starego Testamentu. Litery i znaki, które Jezus wymazał na wieki, nie są wskazówkami do Prawdy, drogowskazem do jakiejś bliżej nieokreślonej tajemnicy,

5 W. Kruszewski, Deus desideratus. Sacrum w poetyckim dziele Tadeusza Różewicza, Lublin 2005, s. 142.

${ }^{6}$ M. Rychlewski, Różewicz, neoawangarda i kryzys logosu, [w:] Logos i mythos w kulturze XX wieku, red. S. Wysłouch, B. Kaniewska, M. Brzóstowicz-Klajn, Poznań 2003, s. 148.

7 M. Januszkiewicz, Horyzonty nihilizmu. Gombrowicz - Borowski - Różewicz, Poznań 2009, s. 336. 
ale zapisem ludzkiej winy (którą w myśl Ewangelii Jezus odkupił na krzyżu). Wymazanie liter, które nastąpi w ostatniej strofie, to zmazanie grzechów Ocalonego, który był prowadzony na rzeź. Grzechy zostały nie tylko zasłonięte, lecz także wymazane. Nietrwałość słów zapisanych na piasku nie musi świadczyć o wymazaniu słów Tajemnicy, zakryciu klucza do Transcendencji. To tylko jedno z możliwych odczytań. Gdy rozszerzy się horyzont kontekstów, okazuje się, że przedmiotem rozważań w tym tekście nie musi być „Pismo”, które zmienia się w „pismo”. Nie musi to być też pogodzenie się z utratą Księgi. Dlatego nie do końca mogę zgodzić się z opinią Leszka Szarugi piszącego o utracie horyzontu Księgi. Według niego utrata ta jest skutkiem zerwania ciągłości rzeczywistości, spowodowanego wojną.

Dwa specjalnie podkreślone przez Szarugę w przywołanym cytacie słowa: „pisał” i „wymazał”, organizują znaczeniowo cały tekst. W zależności od obranych kontekstów, można mu nadać różne znaczenia. Nie jest mym celem rozstrzygać o słuszności któregokolwiek z odczytań. Pragnęłabym jednak zwrócić uwagę na możliwość interpretacji, która wciąż jeszcze nie została wydobyta.

W tomie Regio znajduje się jeszcze jeden tekst, który warto przywołać w kontekście omawiania kwestii Logosu ewangelicznego w poezji Tadeusza Różewicza. Mowa o utworze ***rzeczywistość, który doczekał się komentarza między innymi Nycza ${ }^{8}$, Drewnowskiego ${ }^{9}$, Wiśniewskiego ${ }^{10}$, Witosz ${ }^{11}$ czy Sawickiej ${ }^{12}$. Jak słusznie zauważa ta ostatnia:

Wiersz w istocie konotuje sprzeczne kody odbioru, uruchamiane nawet bez dopełnienia go wykluczającymi się szeregami intertekstów. Jego nierozstrzygalność jest w pełni zgodna z autorskim zamiarem i analogiczna do widzenia przez Różewicza rzeczywistości: dysponujemy zaledwie obrazem (zapisem doświadczenia), którego sens i ocena leży w naszej gestii. W zależności od tego, który szereg intertekstów przyjmiemy, inna będzie wymowa [***rzeczywistości...].

\section{IV}

rzeczywistość

którą oglądałem

przez brudną szybę

w poczekalni

$[\ldots]$

8 R. Nycz, Tekstowy świat. Poststrukturalizm i wiedza o literaturze, Kraków 1993, s. 139.

9 T. Drewnowski, Walka o oddech. O pisarstwie Tadeusza Różewicza, Warszawa 1990, s. 253.

10 J. Wiśniewski, Dlaczego Różewicz. Wiersze i komentarze, Łódź 1993, s. 104-117.

11 M. Witosz, Słowo i milczenie w poezji Tadeusza Różewicza końca XX i początku XXI wieku, http://www.digitalsilesia.eu/Content/11971/doktorat2848.pdf [dostęp: 12.02.2016].

12 K. Sawicka, Stowo wobec rzeczywistości - o poezji Tadeusza Różewicza, „Słupskie Prace Filologiczne. Seria Filologia Polska” 2009, nr 7, s. 148-158. 
Wiersz rozpoczyna się leksemem o wysokim stopniu ogólności, co otwiera możliwość interpretacji w perspektywie ontologicznej. „Rzeczywistość” mieści w swym znaczeniu wszystko, co istnieje — zarówno obserwable, jak i pojęcia. Istnieje ona obiektywnie, sama przez się, niezależnie od postrzegania, rozumienia i myślenia, ale poddaje się poznaniu i badaniom empirycznym. Rzeczywistość przeciwstawia się temu, co jedynie możliwe i pozorne. Zwyczajowo wymienia się trzy najważniejsze właściwości rzeczywistości. Po pierwsze, istnieje ona trwale, także wtedy, gdy nie jest postrzegana, o czym już wspomniałam. Po drugie, wymienia się zdolność bycia przedmiotem poznania. I po trzecie w końcu, rzeczywistość ma zdolność wywoływania efektów przyczynowo-skutkowych, przy czym przyczyna nie musi być znana. $Z$ jednej strony pierwszy wers można potraktować metonimicznie i przyjąć rzeczywistość jako fragment i wycinek widziany przez szybę w poczekalni. $Z$ drugiej strony warto pokusić się o poszerzenie perspektywy i potraktować rzeczywistość jako całość i poczekalnię jako (nieco już wytartą, ale przez to aktualizowaną intuicyjnie) metaforę życia ${ }^{13}$. Byłoby to oczekiwanie pomiędzy narodzinami i śmiercią. Potraktowanie „rzeczywistości” jako całości oraz „poczekalni” jako metafory całości egzystencji pozwala „brudną szybę” potraktować jako symbol epistemologicznych zdolności człowieka. Rzeczywistość odbiera zatem podmiot liryczny niejako podwójnie zniekształconą. Po pierwsze, szyba sprawia, że podmiot nie ma do niej bezpośredniego dostępu. Jeszcze bardziej utrudnia sytuację fakt, że szyba jest brudna, co tylko intensyfikuje poczucie niedoskonałości ludzkiego poznania.

\section{V}

Mając na uwadze opisaną sytuację epistemologiczną, dość zaskakujące wydają się kolejne wersy wiersza:

ujrzałem

twarzą w twarz

$[\ldots]$

13 Podobny wniosek wyciąga Jerzy Wiśniewski w szkicu $W$ poczekalni. Pisze on: „Pierwsza część wiersza jest odwołaniem do sytuacji charakterystycznej dla podróżnego. Opowiadający przywołuje pojęcie poczekalni; mógłby, znalazłszy się w niej, spoglądać poprzez brudne szyby na otoczenie. [...] poczekalnia — może być symbolem ludzkiej egzystencji, której zasadą jest bierne oczekiwanie, w ostateczności sprowadzone do poddania się biegowi czasu i wydarzeń; śmierć jest kresem i wypełnieniem tego oczekiwania. Człowiek, jak podróżny w poczekalni, nie robi nic — tylko czeka. Życie jest procesem, w którym — na wzór sytuacji zaistniałych w poczekalni — zdarzenia przypadkowe dominują nad celowymi, i w którym chaos dominuje nad harmonią. Poczekalnia to także symbol takiego miejsca, z którego w specyficzny sposób można widzieć to, co znajduje się »na zewnątrz«". Zob. J. Wiśniewski, op. cit., s. 107. 
Czasownik ,ujrzeć” niejako antycypuje rangę wydarzenia „,spotkania twarzą w twarz". Jest to leksem, który zakłada momentalność i nieodwracalność zdarzenia, do którego leksem ów się odnosi (Sawicka posługuje się opozycją oglądaćujrzeć, w której pierwszy przeciwczłon dopuszcza trwanie, nawet nieskończenie długo; być może dlatego właśnie święci o g lą d a ją Boga w wieczności).

Rzeczywistość, nawet jeśli została „ujrzana” tylko raz, nie może już powrócić w świadomości podmiotu do swego poprzedniego obrazu, chyba że zechce on wymazać wiedzę o niej z pamięci. Oznaczałoby to jednak okłamywanie nie tylko samego siebie, ale też innych, skoro ten ,podmiot" jest dysponentem słowa nazywającego rzeczy tego świata ${ }^{14}$.

Sawicka zwraca uwagę również na wartości epistemologiczne, gdyż — znów w opozycji do 'oglądania' — ujrzenie wiązać się musi z widzeniem rozumiejącym $^{15}$. „Ujrzeć znaczy zobaczyć naprawdę, a więc zrozumieć. »Ujrzeć twarzą w twarz« to, w świetle poglądów Różewicza, podjąć wyzwanie i przejąć odpowiedzialność za to, co zostało ujrzane"16. Według Nycza wydarzenie to jest objawieniem prawdy o charakterze fundamentalnym i:

[Epifania - przyp. D.M.] daje [...] poczucie rzeczywistości istotnej i punkt oparcia poza ,piaskami słów”. Słowa poety naznacza (topos wybrania, powołania poetyckiego) własną obecnością, czyniąc z niego uprzywilejowanego pośrednika (wariant toposu wieszczego natchnienia), a z jego poezji szczególnie wiarygodne świadectwo prawdy i transcendentnych wartości: słowo, w którym odciśnięto „znak” transcendencji, jest bowiem śladem ,indeksowo” [...] zaświadczającym jej istnienie i oddziaływanie ${ }^{17}$.

Ta etyczna odpowiedzialność ma zakorzenienie w filozofii Lévinasa, w której etyka miała się stać filozofią pierwszą w miejsce ontologii. Nowa metafizyka za swój pierwszy przedmiot miała wziąć nowego człowieka tak, by już nigdy nie pojawiło się zagrożenie „obojętności na podstawową sytuację etyczną człowieka wobec człowieka"18.

14 K. Sawicka, op. cit., s. 148-158.

15 Podobny wniosek wysnuwa wspominany już Wiśniewski: „Czasowniki określające czynności podmiotu-bohatera wiersza - oglądałem, ujrzałem - są nazwami czynności obserwowania, czyli dokonywania jakiegoś aktu poznawczego. Patrzeć na coś zewnętrznego w stosunku do ludzkiej egzystencji, to znaczy podejmować próby zgłębienia czegoś, od czego jest się oddzielonym, co jest tajemnicą i co może być transcendentne, a zatem niedostępne w pełni ludzkiemu poznaniu. Poczekalnia może być zatem symbolem ludzkiego umysłu, którego akty poznawcze są niedoskonałe".

Zob. J. Wiśniewski, op. cit., s. 107-108.

${ }^{16}$ K. Sawicka, op. cit., s. 148-158.

17 R. Nycz, op. cit., s. 40.

18 K. Wieczorek, Lévinas a problem metafizyki, Katowice 1992, s. 12. 
Spróbujmy na chwilę zatrzymać się przy problematyce twarzy w poezji Różewicza ${ }^{19}$, gdyż podmiot liryczny $* * *$ rzeczywistości mówi, iż owo „ujrzenie” odbyło się „twarzą w twarz”. Andrzej Skrendo wymienia cztery najważniejsze sposoby i funkcje występowania motywu twarzy w pisarstwie autora Regio. Jako znak tożsamości osoby występuje twarz w opozycji do maski. Dalej, drugą funkcję pełni twarz jako opozycja do anonima - tak przecież istotnej figury w twórczości Różewicza. „Po trzecie, [...] utwory Różewicza przedstawiają epifanie twarzy, obrazy jej zjawiania się lub rozpadu ${ }^{20 "}$. Jako czwartą funkcję, która co prawda różny się rodzajem od pozostałych — twarz staje się istotnym elementem fabularnym w prozie pisarza ${ }^{21}$. „Jeśli literatura niejako wypowiada twarz, jeśli twarz mówi i tylko w literaturze mowa ta osiąga czystość wyrazu, to w dziele Różewicza znajdujemy wiele tego dowodów, wiele zapisów epifanii twarzy"22. Katarzyna Sawicka pisze o swoistej „obsesji twarzy” u autora Regio, która w tym, jak to ujmuje badaczka, „obiegowym haśle” pozwala poszukiwać sensów wykraczających poza tradycję biblijną i — nieco słabiej słyszalną dla czytelnika o przeciętnych kompetencjach kulturowych — platońską. O twarzy mówi Różewicz w Przygotowaniach do wieczoru autorskiego:

Twarz ludzka była dla mnie i jest krainą, okolicą, krajobrazem, obrazem. Krajobraz twarzy. Twarze rodziców. Twarze rodzeństwa. Twarze obcych. Twarze znajome z widzenia. Twarze żywych ludzi [...] Z ogromną zachłannością wpatrywałem się w te twarze. Piękne i brzydkie, stare i młode, interesujące i nijakie. Myślałem: „Tysiąc, sto tysięcy, milion twarzy — każda inna. Każda przez kogoś kochana, nienawidzona, oczekiwana. Tak, to jest największy temat, jaki czeka na mnie od kilku kat... Twarze. Poemat o twarzach ludzkich. Co wyłaniają się tylko na chwilę i giną, znikają aż do końca świata.. [...] Zdaje mi się, że twarze łączą się w twarz ludzkości i to jest twarz ogromna [...]. Ta twarz jest jedynym obliczem Boga po śmierci Pana Boga ${ }^{23}$.

Twarz jest zarówno „krainą”, czymś odległym i nieznanym, jak i okolicą — czymś bliskim i oswojonym. W twarzy odkrywa się osobę, w twarzy ukryta jest tożsamość. ,Jedyną drogą sprawdzenia tożsamości jest relacja z drugim, konkretnym człowiekiem ${ }^{24}$ ". W kontekście czytanego już utworu bez końcówka przytoczonego fragmentu wydaje się bardzo dobitna. Boga można znaleźć, ale już nie jest to Bóg odległy — można go odnaleźć w drugim człowieku i to właśnie jest najważniejszy i najdonioślejszy ludzki etyczny obowiązek.

19 Tematem tym zajmował się między innymi Skrendo w książce Tadeusz Różewicz i granice literatury: poetyka i etyka transgresji, Kraków 2002 oraz Łukasiewicz w książce TR, Kraków 2016, s. $131-141$.

${ }^{20}$ A. Skrendo, op. cit., s. 336.

21 Zob. ibidem.

22 Ibidem, s. 347.

23 T. Różewicz, Twarze, [w:] Proza, t. 2, Wrocław 2004, s. 267-268.

24 M. Adamska, Tadeusz Różewicz - autoportret poetycki pisany z pamięci, „Konteksty Kultury” 2015, z. 2, s. 239. 
Powróćmy do samego tekstu ***rzeczywistości. „Doświadczenie mistyczne bliskie bezpośredniemu obcowaniu w wieczności zbawionej duszy z Bogiem, równoznaczne z Jego ostatecznym poznaniem w »poczekalni« życia ziemskiego rozgrywać się może jedynie w perspektywie wiary 25 ”. Pismo Święte w kwestii możliwości oglądania Boga podaje w różnych miejscach sprzeczne informacje. W Ewangelii wg św. Jana czytamy: „Boga nikt nigdy nie widział, Ten Jednorodzony Bóg, który jest w łonie Ojca, [o Nim] pouczy" (J 1, 18). Podobnie w Księdze Wyjścia:

I znowu rzekł: „Nie będziesz mógł oglądać mojego oblicza, gdyż żaden człowiek nie może oglądać mojego oblicza i pozostać przy życiu”. I rzekł jeszcze Pan: „Oto miejsce obok Mnie, stań przy skale. Gdy przechodzić będzie moja chwała, postawię cię w rozpadlinie skały i położę rękę moją na tobie, aż przejdę. A gdy cofnę rękę, ujrzysz Mnie z tyłu, lecz oblicza mojego tobie nie ukażę" (Wj 33, 20-23).

Z drugiej strony znamy Mojżesza jako tego, który rozmawiał z Bogiem „twarzą w twarz" (Wj 33, 11). Rodziców Samsona w przerażenie wprawiła myśl, że właśnie spotkali się z Bogiem (Sdz 13, 22). Kontekst całego Pisma Świętego nie pomaga rozwikłać tego fragmentu teksu Różewicza. Pozostać jednak należałoby przy najbardziej oczywistym intertekście, jakim jest trzynasty rozdział Pierwszego Listu świętego Pawła do Koryntian:

Teraz widzimy jakby w zwierciadle, niejasno;

wtedy zaś [zobaczymy] twarzą w twarz:

Teraz poznaję po części,

wtedy zaś poznam tak, jak i zostałem poznany.

To poetyckie ujrzenie twarzą w twarz (najprawdopodobniej) Boga zawiera w sobie zwłaszcza dwie z czterech wymienionych przez Skrendę funkcji. Po pierwsze, w sytuacji boskiej epifanii nie ma miejsca na anonimowość. Według Katechizmu Kościoła Katolickiego (KKK 2158) „Bóg wzywa każdego po imieniu (por. Iz 43, 1; J 10, 3). Imię każdego człowieka jest święte. Imię jest ikoną osoby. Domaga się szacunku ze względu na godność tego, kto je nosi"26. Epifania jest wezwaniem przez Boga - nie może ono odbyć się anonimowo, Bóg musi wezwać człowieka po imieniu ${ }^{27}$, by ten mógł ujrzeć go twarzą w twarz. Pozostańmy jeszcze przez chwilę przy chrześcijańskiej wykładni imienia:

Bóg objawił się Izraelowi, swemu ludowi, pozwalając mu poznać swoje imię. Imię wyraża istotę, tożsamość osoby i sens jej życia. Bóg ma imię; nie jest jakąś anonimową siłą. Ujawnić swoje

25 J. Wiśniewski, op. cit., s. 109.

26 Wszystkie cytaty z KKK pochodzą z: Katechizm Kościoła Katolickiego, wyd. II poprawione, Poznań 1992.

27 W Księdze Izajasza stosowny fragment brzmi następująco: „Ale teraz tak mówi Pan, Stworzyciel twój, Jakubie, i Twórca twój, o Izraelu: »Nie lękaj się, bo cię wykupiłem, wezwałem cię po imieniu; tyś moim!«”. W Ewangelii św. Jana zaś: „Temu otwiera odźwierny, a owce słuchają jego głosu; woła on swoje owce po imieniu i wyprowadza je". 
imię oznacza pozwolić, by inni mogli nas poznać, w jakiś sposób ujawnić siebie, stając się dostępnym, możliwym do głębszego poznania i do bycia wzywanym po imieniu ${ }^{28}$.

Spotkanie twarzą w twarz w tej niezmiernie specyficznej sytuacji implikuje znajomość imienia i osoby. Świat poznajemy przez brudną szybę, aczkolwiek dzięki epifanii dane jest nam poznanie czyste i nieskażone. Zdaje się, że przynajmniej przez ten moment wyznaczany przez czasownik „ujrzeć” człowiek dostępuje możliwości niezapośredniczonego i doskonałego poznania. Nie może jednak uzyskać tego sam, jest uzależniony od tego, który się ukaże i tego, co się ukaże. Po drugie, nie może być sam, gdyż — jak już wyjaśniłam — epifania wymaga wejście w osobistą relację. Twarz zatem jawi się tutaj jako opozycja anonima. Twarz jest jednostkowa, zawsze inna, łączy się z tożsamością osoby. Dlatego właśnie ujrzenie twarzą w twarz ma takie znaczenie. Ma ono wymiar epistemologiczny i etyczny, gdyż spotkanie z twarzą zawsze zawiera w sobie konieczność gestu etycznego, o którym była już mowa.

„Etyczność” polega zatem na przyjęciu przez podmiot postawy — by tak rzec — etycznej gotowości, nie wynika zaś z odnalezienia jakiejś trwałej identyfikacji. Nie daje jej (tej identyfikacji) ani filozofia, ani religia, ani społeczne obyczaje. Jej ostoję stanowi doświadczenie poetyckie, czyli doświadczenie kruchości rzeczy, doznawanie przebywania na granicy. Ta granica najpełniej manifestuje się w obrazach i epifaniach twarzy ${ }^{29}$.

Tutaj właśnie - w owej „etyczności”, którą determinuje dostrzeżenie twarzy (czy też jej objawienie), Skrendo upatruje drugiej funkcji twarzy w pisarstwie Różewicza. Dla moich rozważań szczególnie ważna jest, po pierwsze, sama konieczność zatrzymania się przy Różewiczowskim fenomenie twarzy, otwierająca drogę do intertekstów biblijnych i filozoficznych oraz potęguje siłę tego symbolu. Po drugie, fakt rozwarstwienia tych intertekstów, który po raz kolejny wskazuje na palimpsestowy charakter twórczości autora Twarzy trzeciej. To, co uda się odkryć, zależy głównie od tego, jak wiele warstw potrafimy odtworzyć i jak delikatnie będziemy obchodzić się z tekstem, by jednym nieostrożnym posunięciem podczas procesu odtwarzania znaczeń, nie zniszczyć tego, co jeszcze pozostało pod spodem.

Bóg nie tylko nie jest daleko, lecz także istnieje tuż obok. Wydaje się zatem, że jest wręcz odwrotnie, niż mówi o tym Skrendo, cytując Tadeusza Gadacza: „Gdy Bóg jest nieobecny, jeden za drugiego bierze odpowiedzialność” ${ }^{30}$. Właśnie dlatego, że Bóg jest obecny w drugim człowieku, mamy obowiązek wziąć za niego odpowiedzialność. „Etyka wynika z bezpośredniości twarzy, z jej obcości, podatności na zranienie, z jej nagości” ${ }^{31}$. W telewizyjnej rozmowie z Janowską

28 KKK 203.

29 A. Skrendo, op. cit., s. 357-358.

30 Zdanie pochodzi z wstępu do książki O Bogu, który nawiedza myśl, s. 13. Cyt. za A. Skrendo, op. cit., s. 346.

31 Ibidem, s. 345. 
i Mucharskim, Różewicz mówi, że ,gdy nie ma Boga, to nie wolno niczego, bo nikt nie odpuści mi moich win, sam sobie muszę je odpuszczać ${ }^{32}$. Dlatego wydaje mi się, że Bóg Różewicza to raczej Jezus niż Bóg Ojciec. Jest to Bóg bardzo ludzki, cierpiący wraz z człowiekiem, bliski, Bóg, który, przychodzi, nie — który jest. Do wątku tego powrócę jeszcze przy podsumowaniu niniejszych rozważań, próbując odtworzyć obraz Jezusa-Logosu w poetyckim dziele Różewicza.

\section{VII}

Symptomatyczna jest reakcja podmiotu lirycznego na to, co zobaczył „twarzą w twarz":

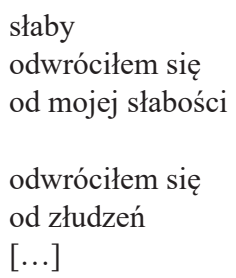

Można fragment ten czytać na dwa radykalnie odmienne sposoby. Człowiek wobec tego, co zjawia mu się w epifanii, jest słaby i odwraca się od złudzeń, którymi są Bóg i metafizyka. To jest jedna z możliwych interpretacji i taki ton przeważa w istniejących już odczytaniach *** rzeczywistości.

Odwrócić się od słabości można w stronę mocy. Może ten moment jest właśnie tym zwrotnym w życiu $\mathrm{TR}^{33}$, momentem, w który odrzuca się złudzenia, dociera do istoty rzeczywistości, do epistemologicznie pewnego poznania. Wydaje $\mathrm{mi}$ się, że interpretowanie tego fragmentu $\mathrm{w}$ innym duchu jest niezgodne $\mathrm{z}$ literą tekstu. Przyimek ,od” jednoznacznie wskazuje zmianę zwrotu (przy czym rozumiem tu „Zwrot” wektorowo). Nie wiemy, czy kierunek pozostaje ten sam. Być może nie będzie tu mowy o opozycjach. Aczkolwiek na pewno TR przy swoich słabościach i złudzeniach nie pozostaje. Dlatego nie zgadzam się z interpretacją Nycza, który pisze o odkrywaniu prawdy, że nie istnieje świat inny „niż ten, który poznajemy w potocznym doświadczeniu. Myśleć inaczej to [...] okazywać słabość i popadać w złudzenia: bo słaby jest ten, kto nie może polegać na sobie i musi szukać oparcia poza sobą; łudzi się — kto się kieruje iluzjami innej, prawdziwszej realności" 34 . Bardzo blisko mi natomiast do odczytania Wiśniewskiego, który w słowach podmiotu lirycznego widzi: „akt analogiczny nawróceniu, które

32 Takie zdanie wypowiada Różewicz w telewizyjnej rozmowie z K. Janowską i P. Mucharskim, cytat za: A. Skrendo, op. cit., s. 346.

33 TR to konstrukt stworzony przez Jacka Łukasiewicza. Według wrocławskiego badacza podmiotem poezji Różewicza jest byt sylleptyczny, będący swego rodzaju połączeniem biografii Różewicza i jej tekstowymi, poetyckimi wariantami. Por. J. Łukasiewicz, TR, Kraków 2012.

34 R. Nycz, op. cit., s. 143-144. 
przejawia się w człowieku po pierwsze poprzez pokorną świadomość własnej słabości, a po drugie poprzez dążenie do radykalnego przewartościowania swojej postawy”35. Mimo, iż: „w drugiej części wiersza, którą można odczytywać jako świadectwo duchowego przewartościowania, na pierwszy plan wysuwa się jednak świadomość słabości wewnętrznej człowieka; kształt wersyfikacyjny monologu-wyznania akcentuje słowo słaby" "36, to ów akcent nie wybrzmiewa w kontekście całości wiersza. Słabość jest tylko etapem, który prowadzi do metanoi.

\title{
VIII
}

Ostatnia część wiersza jest bez wątpienia najważniejsza, poświęcono jej także najwięcej miejsca w opracowaniach naukowych.

\author{
na piaskach \\ moich słów \\ ktoś nakreślił znak \\ ryby \\ i odszedł
}

Jak słusznie zauważa Ryszard Nycz: ,przez kontaminację formuł Platońskich i Pawłowych, wpisanych w obiegowe frazy języka potocznego, przywołane zostają grecko-chrześcijańskie tradycje fundujące paradygmatyczny — przynajmniej dla europejskiego kręgu kulturowego - wzorzec kulturowy"37. Przeanalizujmy wyłaniające się po kolei znaczenia. Piasek przeciwstawiany jest skale w Ewangelii św. Mateusza we fragmencie, gdzie charakteryzuje się człowieka roztropnego, który swój dom stawia na solidnym fundamencie (Mt 7, 24-29). W innym ważnym miejscu Jezus nazywa św. Piotra skałą-opoką, na której zbuduje swój Kościół. Człowiek nieroztropny to ten, który nie słucha Słowa Bożego — jego dom postawiony został na piasku. Słowa TR nie są nawet słowami na piasku - są piaskiem słów. W 1962 roku Różewicz pisze notatkę Zamek na lodzie, w której sformułowanie to ma dokładnie to samo brzmienie. Omawiając metaforę „kamieniołom katedry milczał", pisze:

Z obrazem kamieniołomu (w mojej wyobraźni) łączy się puste miejsce otoczone skałami, a właściwie w skałach i wypełnione powietrzem. Nic. Miejsce po czymś. [...] Gdybym unieruchomił i utrzymał w powietrzu ten nowy kształt [...] może to nowe zjawisko, ta nowa konstrukcja byłaby bliższa pierwotnej koncepcji niż ten „kamieniołom katedry”. Ale i w tej barokowej babce z piasku (słów) jest jakaś ,„piękna” przesada ${ }^{38}$.

35 J. Wiśniewski, op. cit., s. 109.

36 Ibidem, s. 112.

37 R. Nycz, op. cit., s. 139.

38 T. Różewicz, Zamek na lodzie, [w:] Przygotowanie do wieczoru autorskiego, Warszawa 1971, s. 113-114. 
Za interesujące można uznać tutaj wykorzystanie kolejnego symbolu związanego z chrześcijaństwem. Pustka, która pozostała po katedrze, musi milczeć, gdyż opuściło ją już „Słowo żywe” - straciła swe znaczenie kulturotwórcze. Babka z piasku słów może być piękna, ale — jednak — jest nietrwała.

Podobne znaczenie ewokuje fragment wiersza ***rzeczywistość. „Piaski słów" są metaforą słabości słowa nieumocowanego w czymś wykraczającym poza nie samo. Można się spierać, czym jest owa transcendencja, aczkolwiek wydaje się, że nie można zaprzeczyć jakiejś jej obecności. Zwłaszcza gdy weźmiemy pod uwagę kolejne wersy tekstu. Dlatego nie zgadzam się z Nyczem, który pisze:

Domniemany ślad transcendencji — „ktoś nakreślił znak / ryby” — odczytany w kontekście bliższym: „na piaskach [...] ktoś nakreślił znak”; oraz dalszym: „każdy znak można / na mnie wycisnąć" (Rozmowa z księciem, P) — podlega z konieczności relatywizacji i problematyzacji, lub nawet zakwestionowaniu ${ }^{39}$.

Umieśćmy jeszcze gest kreślenia na pisaku w kontekście ewangelicznym. Jezus pisze na piasku tuż przed przebaczeniem kobiecie cudzołożnej. Pytaniem, które do dziś nurtuje biblistów i egzegetów, jest treść słów, które Jezus wypisał na ziemi. Ciekawą interpretację tej sytuacji dał św. Augustyn. Jezus miałby wypisywać jedno słowo - „cudzołóstwo”, a następnie słowo to rozwiewał wiatr tak, że znikało na wieki. Św. Augustyn widzi tu symbolikę odpuszczenia grzechów, które wobec miłosierdzia Boga miałyby być bez znaczenia. Na to, że Jezus mógłby zapisywać na ziemi grzechy, świadczy fragment Starego Testamentu, a konkretnie - wspominanej już przy okazji mówienia o Nieznanym liście — księgi Jeremiasza:

Nadziejo Izraela, Panie!

Wszyscy, którzy Cię opuszczają, będą zawstydzeni.

$\mathrm{Ci}$, którzy oddalają się od Ciebie, będą zapisani na ziemi,

bo opuścili źródło żywej wody, [Pana] (Jr 17, 13).

Ktoś, czyjego imienia nie znamy, ale raczej bezbłędnie identyfikujemy jako Chrystusa, kreśli na piasku. Jest to gest unieważnienia. Piaski słów — słowa rozmnożone, które nie mają zakorzenienia w Logosie — zostają zapisane na ziemi, „bo opuściły źródło wody żywej”.

\section{IX}

Znak ryby jest nakreślony przez „kogoś”, kto jest dość łatwy do identyfikacji: „Nietrudno dostrzec w tej frazie aluzję do zbawczego znaku Chrystusa (Ichtys), spod którego — tak jak spod frazy Pawłowej [...] — przebija również grecki kontekst: ryby (gr. orphos) jako symbolu Orfeusza"40. Nie jest to jednak jedyna warstwa znaczeń, która przebija spod symbolu ryby. W najbliższej nam tradycji chrześcijańskiej Jezus, powołując Szymona Piotra (opokę-skałę, na której Chry-

39 R. Nycz, op. cit., s. 144.

40 Ibidem, s. 140. 
stus miał zbudować swój Kościół), mówi do niego, że od teraz apostoł będzie łowił ludzi. Jest to moment nawrócenia Piotra. Podobnie jak apostoł, podmiot liryczny wiersza ***rzeczywistość odwraca się od swoich złudzeń i słabości. Pobrzmiewają w tym wezwaniu echa orfickie. Piotr będzie wyciągał dusze ku światłu — ku Bogu. Podobnie jak Piotr w Ewangelii wg św. Łukasza, TR przyznaje się do swojej słabości w momencie „ujrzenia twarzą w twarz”. Piotr zarzuca sieci „na słowo" Chrystusa i nie zawodzi się, wbrew pierwszemu zwątpieniu. Poprzez „łowienie" ludzi dla Chrystusa ma łowić ich także do życia prawdziwego i w efekcie - do życia wiecznego. W tym miejscu warto też wspomnieć o jeszcze jednym ewangelicznym momencie - rozmnożeniu chleba i ryb. Pierwsi chrześcijanie oprócz chleba i wina, które do dziś pozostały w liturgii chrześcijańskiej, spożywali też ryby — na malowidłach w katakumbach ryba oznaczała eucharystię, do IX wieku na przedstawieniach Ostatniej Wieczerzy oprócz chleba i wina widniała także ryba. Ichthys-ryba to akrostych samego Mesjasza. Bohater wiersza otrzymał znak o randze znaku wiary, jak też znaku służącego tajnemu porozumieniu i przypominaniu o świętej tajemnicy ${ }^{41}$.

Wszystkie te treści wybrzmiewają $\mathrm{W}$ znaku ryby $\mathrm{w}$ utworze $* * * r z e c z y w i-$ stość. Znak ryby nakreślony przez nienazwanego z imienia „kogoś” zawiera w sobie gest fundujący rzeczywistość — gest nakreślenia ryby, niejako ustanowienia chrześcijaństwa (wszak od tego momentu liczy się nasz zachodnioeuropejski czas) jest gestem założycielskim jednego z filarów cywilizacji zachodniej. Ryszard Nycz nie zgadza się z takim odczytaniem i pisze,

[...] domniemany ślad transcendencji — „ktoś nakreślił znak / ryby” [...] podlega z konieczności relatywizacji i problematyzacji, lub nawet zakwestionowaniu. Stać się bowiem może znakiem czegoś, co nigdy naprawdę nie było obecne... gdzie indziej niż w zwodniczej i ,życzeniowej” grze ludzkiego języka... ${ }^{42}$

Zarówno w tekście *** rzeczywistość, jak i w Nieznanym liście kontekst biblijny jest podstawą do zrozumienia wymowy tekstu. Oczywistość ta wynika z powszechności kompetencji kulturowej dotyczącej takich symboli, jak ryba, gestów jak kreślenie na piasku czy postaci jak Jezus. Interpretacje w duchu nihilizmu bez wątpienia skupiają się na eliminowaniu znaczeń — jest to poezja bez Boga, bez metafizyki, bez wartości etc. Wydaje się jednak, że w odniesieniu do poezji Różewicza znaczenia należałoby raczej wydobywać i głębiej badać konteksty oraz interteksty. W przypadku Nieznanego listu i ***rzeczywistości użytecznym intertekstem okazuje się starotestamentalna Księga Jeremiasza pozwalająca interpretować wydźwięk tych wierszy jako optymistyczny — wbrew dotychczasowym odczytaniom, w których podkreślano wymazanie Tajemnicy, nieistnienie Transcendencji czy przejście z perspektywy „Księgi” do „księgi”.

41 J. Wiśniewski, op. cit., s. 113-114.
42 R. Nycz, op. cit., s. 143-144. 


\title{
Two apocrypha of Różewicz reading in context of a few verses of the Book of Jeremiah
}

\begin{abstract}
Summary
The article Two apocrypha of Różewicz reading in context of a few verses of the Book of Jeremiah discusses one of the key problems of the poetry of Tadeusz Różewicz - intertextuality. Additional context is created by Bible. Thanks to an analysis of texts we can show, that it is possible to reinterpret two poems of Różewicz because of two verses of the Book of Jeremiah, The discussion is based on the poem [reality...] from the Regio collection and Unknown letter from Conversation with the Prince collection. Through the thesis that this poem is a record of a positive epiphany the article attempts to argue with the accepted in literary criticism interpretation of Ryszard Nycz, Monika Witosz and Katarzyna Sawicka.
\end{abstract}

